\title{
INFLUENCE OF STABILIZATION EXERCISES ON ARTICULAR CARTILAGE CHANGES IN DEGENERATIVE TIBIOFEMORAL JOINT DISEASE: A PILOT STUDY
}

\author{
PATCHAVA APPARAO ${ }^{1 *}$, SUDHAKAR $\mathrm{S}^{2}$, GANAPATHI SWAMY $\mathrm{CH}^{3}$, RAVI SHANKAR REDDY $\mathrm{Y}^{4}$ \\ ${ }^{1}$ School of Physiotherapy, Vels University Chennai, Tamil Nadu, India. ${ }^{2}$ Department of Arthroscopy \& Sports Medicine, Sri Ramachandra \\ Medical College, Chennai, Tamil Nadu, India. ${ }^{3}$ Department of Community Medicine, GSL Medical College, Rajahmundry, Andhra Pradesh, \\ India. ${ }^{4}$ Department of Physiotherapy, King Khalid University, Abha, Saudi Arabia. \\ Email: principalsipr@yahoo.com
}

Received: 10 January 2017, Revised and Accepted: 19 January 2017

\section{ABSTRACT}

Objectives: To determine the effectiveness of knee joint stabilization exercises in minimizing articular cartilage degeneration and to examine the effectiveness of knee joint stabilization exercises on decreasing pain, improving range of motion (ROM) and muscle strength.

Methods: About 20 volunteer subjects (age 35-65 years) with primary osteoarthritis fulfilled the inclusion criteria given the knee stabilization exercises for 8 weeks. Pain, muscle strength, functional outcome score, and serum cartilage oligomeric matrix protein (COMP) values were measured pre- and post-intervention using visual analog scale, dynamometer, and ELISA test. Data were analyzed using a paired t-test with Statistical Package for the Social Sciences version 20 to find out the difference between the pre- and post-test.

Results: The results of the study have shown that significant difference between pre- and post-test values of pain, ROM, muscle strength and functional outcome score with $\mathrm{p}<0.05$, and there is statistical in significance in serum COMP value $(\mathrm{p}<0.05)$.

Conclusion: Stabilization exercises of knee joint were shown to be beneficial for decreasing pain, improving ROM and muscle strength, and there was no effect on articular cartilage changes in degenerative tibiofemoral joint disease.

Keywords: Serum cartilage oligomeric matrix protein, Knee stabilization exercises, Proprioception exercises, Muscle strength.

(C) 2017 The Authors. Published by Innovare Academic Sciences Pvt Ltd. This is an open access article under the CC BY license (http://creativecommons. org/licenses/by/4. 0/) DOI: http://dx.doi.org/10.22159/ajpcr.2017.v10i4.17026

\section{INTRODUCTION}

Osteoarthritis $(\mathrm{OA})$ is the most common degenerative joint disease, occurring primarily in older persons, characterized by erosion of the articular cartilage, hypertrophy of bone at the margins and a range of biochemical and morphologic alterations of the synovial membrane and joint capsule [1]. OA is the most common type of arthritis and major health problem worldwide. It effects any joint contains hyaline cartilage and knees are most commonly affected. OA is the most common form of arthritis, accounting for approximately $75 \%$ of the disease and ranking among the top 10 causes of disability worldwide [2]. OA is a leading cause of pain and disability and generally affects women more frequently than men.

Literature is limited on the incidence and prevalence of OA because of the problems of defining it. Worldwide $9.6 \%$ of men and $18 \%$ of women of more than 65 years have symptomatic OA [3]. Males are affected more than females below 45 years, while females are more affected after 45 years [4].

The most cases of OA have no known cause and are referred to as primary OA. Primary OA is mostly related to aging. It can present as localized, generalized or as erosive OA. Secondary OA is caused by another disease or condition. $\mathrm{OA}$ is the second most common rheumatologic problem and is most frequent joint disease with prevalence of 22-39\% in India [5]

There is increasing evidence that physiotherapy, in the form of exercise therapy, is an effective intervention. Exercise is considered the most important intervention in the management of $\mathrm{OA}[3]$

Increased intervention efforts, including early diagnosis and appropriate clinical and self-management (e.g., Physical activity, patient education, and maintaining appropriate weight), are needed to reduce the impact of arthritis and chronic symptoms. Moderate exercise is effective in reducing pain and improving function in knee. However, exercise is underutilized as a therapy for OA and more than $60 \%$ of adults with arthritis do not satisfy the recommendations for physical activity [4].

Research shows that regular, moderate use of normal joints does not increase the risk of $\mathrm{OA}$ and can help maintain overall health, muscle strength and range of motion (ROM)

Physiotherapy helps in increasing flexibility, maintain joint ROM, strengthen surrounding muscles, decrease associated inflammation, and improve overall fitness.

The hallmark of structural changes occurring in the OA joint is cartilage loss. Since OA is considered a wear and tear disease, one identified barrier to exercise is the belief that exercise will not improve or may even be harmful to joint cartilage.

However, with the recent onset of successful treatments for $\mathrm{OA}$, it becomes important to identify prognostic factors that can predict the evolution of arthritis. A valuable approach to monitor arthritis would be by measuring biological markers of cartilage degradation and repair to reflect variations in joint remodeling. One such potential biological marker of arthritis is cartilage oligomeric matrix protein (COMP) [6]

The cartilage oligogomeric matrix protein is a noncollagenous protein, a glycoprotein, the function of which is to bind to type II collagen fibers and stabilize the collagen fiber network in the articular cartilage [7]. COMP consists of five $87 \mathrm{kDa}$ subunits held 
together by interchain disulfide bonds forming a $435 \mathrm{kDa}$ pentameric protein. COMP is expressed in all types of cartilage. It is becoming known that the mechanisms of cartilage matrix destruction such as roles of degradative enzymes and cyrokines, so it is important to develop the reliable biomarkers to detect the early stage of cartilage destruction [6].

The biomarker could be a useful tool not only to understand the progression of the joint destruction in $\mathrm{OA}$ but also to develop new treatment [6]. Numerous physiotherapeutic interventions are available for knee $\mathrm{OA}$ based on symptoms. Lack of literature regarding the effect of stabilization exercises on changes in articular cartilage, and increase in glycoprotein content hence the need of the study arises. The purpose of this study is to determine the effectiveness of knee joint stabilization exercises in minimizing articular cartilage degeneration and to examine the effectiveness of knee joint stabilization exercises on decreasing pain, improving ROM and muscle strength.

\section{METHODS}

This study was a single group pre-test post-experimental design carried out during October 2015 to July 2016 in Department of Physiotherapy, GSL Medical College, Rajahmundry. The study protocol was approved in Ethical Committee of VELS University, Chennai. Subjects with degenerative tibiofemoral joint disease were examined in which 24 subjects matched the inclusive criteria in which 4 students dropped from the study because of personal reasons.

The eligible individuals with following symptoms were included in the study: Subjects with diagnosis of knee OA according to the clinical ACR criteria morning stiffness $<30$ minutes, crepitus, bony tenderness, bony enlargement, primary $\mathrm{OA}$ with Grade 1 and 2 of Kellegrens and Lawrence scale, age group of 35-65 years.

Subjects with a history of knee trauma, previous surgery, deformity, local injections, infection, and obese people were excluded from the study. The recruited subjects were explained the purpose and relevance of the study. Those willing to volunteer were included in the study after obtaining informed consent.

All subjects underwent full history including duration of symptoms, mode of onset, precipitating, and relieving factors. Subject's age, weight, height, and body mass index were determined.

The subjects recruited through simple random were given the 8 week stabilization exercises protocol and procedure [8-16] explained in Tables 1 and 2 .

The dependent variable was pain, muscle strength, ROM, and serum COMP value were measured by visual analogue scale (VAS), dynamometer, universal goniometer and ELISA test, respectively. The investigator was blinded to the measurements. Data were analyzed using a paired t-test with Statistical Package for the Social Sciences version 20 to find out the difference between the pre- and post-test.

\section{OUTCOME MEASURES}

\section{Primary outcome measures}

1. Visual analog scale (VAS) for pain

2. Handheld dynamometer to measure muscle strength.

\section{Secondary outcome measures}

1. ELISA test to measure serum COMP content.

\section{Statistical analysis}

The data were analyzed using paired t-test for finding the difference between the pain, ROM, muscle strength, functional outcome, and serum COMP value before and after the treatment.

\section{RESULTS}

The results of the study have shown that significant difference between pre- and post-test values of pain, ROM and muscle strength with $p<0.05$, and there is statistical in significance in serum COMP value $(p>0.05)$.

Results in Table 3 and Figs. 1-5 indicate that there was significant difference in all variables except COMP value.

The results of the study have shown that significant difference between pre- and post-test values of pain, ROM and muscle strength.

\section{DISCUSSION}

Muscle plays a major role in the structure and function of joints as evidenced by disuse atrophy of the muscles surrounding knee joint. Quadriceps weakness is associated with disability in subjects with knee pain. As the quadriceps is of key importance in walking, standing, and using stairs, muscle weakness may be direct cause of impaired function. $\mathrm{OA}$ of knee affects the hamstring muscles more than the quadriceps; therefore, there is a need for the

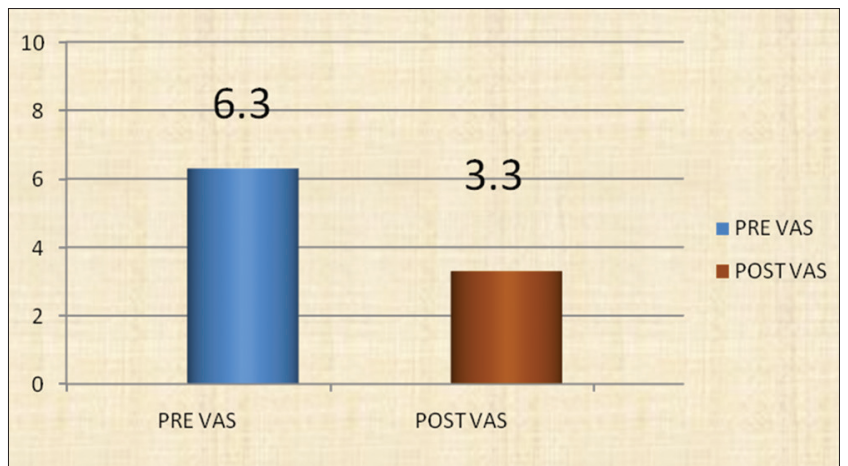

Fig. 1: Visual analog scale score

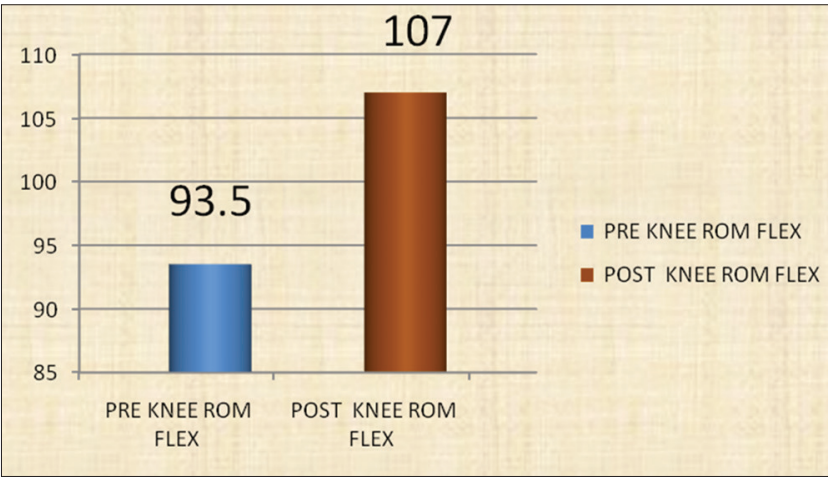

Fig. 2: Knee range of motion

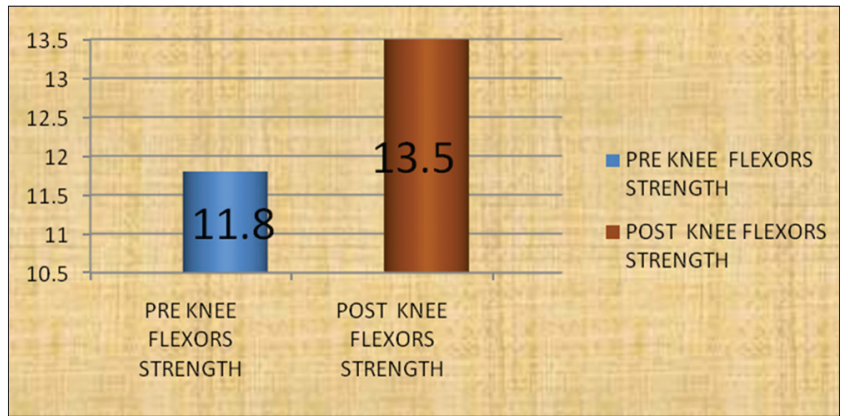

Fig. 3: Knee flexors strength 
Table 1: Stabilization exercises protocol

\begin{tabular}{|c|c|c|c|c|}
\hline Duration & Intervention & Frequency & Duration & Exercises \\
\hline 1-8 weeks & Stretching exercises & Thrice weekly & $\begin{array}{l}1 \text { set } \\
3 \text { repetitions }\end{array}$ & $\begin{array}{l}\text { Hamstring stretch } \\
\text { Quadriceps stretch } \\
\text { Calf stretch } \\
\text { Iliotibial band stretch }\end{array}$ \\
\hline 1-2 weeks & $\begin{array}{l}\text { Isometric exercises } \\
\text { Multi angle isometric exercises } \\
\text { Cocontraction exercises }\end{array}$ & Thrice weekly & $\begin{array}{l}3 \text { sets } \\
10 \text { repetitions }\end{array}$ & $\begin{array}{l}\text { Hamstring } \\
\text { Quadriceps } \\
\text { Rythmic stabilization } \\
\text { Co-contraction }\end{array}$ \\
\hline 3-4 weeks & Active resisted exercises & Thrice weekly & $\begin{array}{l}3 \text { sets } \\
10 \text { repetitions }\end{array}$ & $\begin{array}{l}\text { Straight leg raises } \\
\text { Abductor raise } \\
\text { Adductor raise } \\
\text { Hamstring curl } \\
\text { Quadriceps curl } \\
\text { Heel raise } \\
\text { Wall squats }\end{array}$ \\
\hline 5-6 weeks & Proprioception exercises & Thrice weekly & $\begin{array}{l}3 \text { sets } \\
5 \text { repetitions }\end{array}$ & $\begin{array}{l}\text { One leg balance } \\
\text { Toe walking } \\
\text { Heel walking } \\
\text { Cross body leg swings } \\
\text { Wobble board }\end{array}$ \\
\hline 7-8 weeks & Neuromuscular training exercises & Thrice weekly & $\begin{array}{l}2 \text { sets } \\
3 \text { repetitions }\end{array}$ & $\begin{array}{l}\text { Core stability/postural function } \\
\text { Postural orientation } \\
\text { Step up and step down }\end{array}$ \\
\hline
\end{tabular}

Table 2: Exercise procedure

\begin{tabular}{|c|c|}
\hline Technique & Procedure \\
\hline Hamstring stretch & $\begin{array}{l}\text { Subject in full supine - lying position on a plinth with his two feet pointing upward. The contralateral lower limb was } \\
\text { stabilized. The lower limb being stretched was passively moved into the extreme of extension, up to the limit where } \\
\text { the subject felt a gentle stretch at the posterior aspect of the thigh. This placed the hamstring muscles at their greatest } \\
\text { possible length. The stretch was sustained at this point for } 30 \text { seconds and relax. The procedure was carried out thrice a } \\
\text { week for } 8 \text { consecutive weeks [8] }\end{array}$ \\
\hline Quadriceps stretch & $\begin{array}{l}\text { Subject is in prone, bend one knee, and examiner grab ankle with right hand. Gently push foot toward buttocks until } \\
\text { subject feel a gentle stretch in the anterior aspect of the thigh. Hold the stretch for } 30 \text { seconds and relax. The procedure } \\
\text { was carried out thrice a week for } 8 \text { consecutive weeks [9] }\end{array}$ \\
\hline IT band stretch & $\begin{array}{l}\text { Subject is in up right standing position with normal leg crossed in front of affected leg, Lean slightly forward and to } \\
\text { normal side until subject feel a stretch on the outside of the affected side. Lean on a chair/wall if needed. Hold for } \\
30 \text { seconds and relax. The procedure was carried out thrice a week for } 8 \text { consecutive weeks [9] }\end{array}$ \\
\hline Calf stretch & $\begin{array}{l}\text { Subject made to stand in bare feet with feet shoulder width apart facing a wall with the leg to be stretched behind the } \\
\text { other leg so that the hip and knee of the leg to be stretched were extended, and the contra lateral leg was in front with } \\
\text { the hip and knee in flexion. Once in this position, the subjects were told to lean forward over the front leg as if they were } \\
\text { pushing into the wall with their arms extended in front of them while keeping the heels of both feet flat on the floor until } \\
\text { a stretching sensation was felt over the posterior calf. Emphasis was placed on educating the patients to keep both the } \\
\text { knee and toes pointing straight toward the wall and to avoid rolling the ankle to the outside or inside. The stretch was } \\
\text { held for } 30 \text { seconds followed by a } 10 \text { seconds rest period. The procedure was carried out thrice a week for } 8 \text { consecutive } \\
\text { weeks [9] }\end{array}$ \\
\hline Hamstrings & $\begin{array}{l}\text { Subject supine on the a bed or sitting with knee bent knee approximately } 45^{\circ} \text { press heel into the floor or bed as much as } \\
\text { you can. Hold this position for } 5-10 \text { seconds and relax } 3 \text { sets of } 10 \text { repetitions thrice a week for } 2 \text { weeks }\end{array}$ \\
\hline Quadriceps & $\begin{array}{l}\text { Patients lay in a supine position. A rolled-up towel was put beneath the knee. They were instructed to maximally activate } \\
\text { their thigh muscles to straighten their knee and hold the contraction for } 5-10 \text { seconds and relax, } 3 \text { sets of } 10 \text { repetitions } \\
\text { thrice a week for } 2 \text { weeks [10] }\end{array}$ \\
\hline $\begin{array}{l}\text { Multiple angle } \\
\text { hamstrings }\end{array}$ & $\begin{array}{l}\text { The subject lies on their front in the prone position. The therapist provides resistance as the subject contracts the } \\
\text { hamstring muscles, holds for } 10 \text { seconds then relaxes. The angle of knee flexion is changed and the exercise repeated. } \\
\text { Once a range of angles have been worked the whole process is repeated with the foot first turned first inward then } \\
\text { outward. This exercise targets the inner and outer hamstring muscles at varying angles }\left(30,45,60 \text { and } 90^{\circ}\right) \text { of } \\
\text { flexion [11] }\end{array}$ \\
\hline $\begin{array}{l}\text { Multiple angle } \\
\text { quadriceps }\end{array}$ & $\begin{array}{l}\text { Quadriceps strengthening by full exetension of knee joint against } 3 \mathrm{~kg} \text { resistance with sand bag in high sitting position } \\
\text { hold it for } 10 \text { seconds and followed by rest for } 5 \text { seconds. Again strengthening by } 45^{\circ} \text { of flexion from exetension against } \\
3 \text { kg resistance and hold it for } 10 \text { seconds and rest for } 5 \text { seconds [11]. } 3 \text { sets of } 10 \text { repetitions thrice a week for } 2 \text { weeks }\end{array}$ \\
\hline
\end{tabular}


Table 2: (Continued)

\begin{tabular}{|c|c|c|}
\hline Technique & \multicolumn{2}{|c|}{ Procedure } \\
\hline Rhythmic stabilization & \multicolumn{2}{|r|}{$\begin{array}{l}\text { Subject is an upright position with one leg flexed and foot rested on a box. The knee joint angle was approximately } \\
60-70^{\circ} \text {, examiner placed his hands above and below the subjects knee joint and encouraged the subject to hold the leg } \\
\text { in same position, while manually applying moderate pressure in a rhythmic fashion from various angles to the distal and } \\
\text { proximal parts of the thigh and lower leg, respectively, } 3 \text { sets of } 10 \text { repetitions thrice a week for } 2 \text { weeks [13] }\end{array}$} \\
\hline Straight leg rises & \multicolumn{2}{|r|}{$\begin{array}{l}\text { Subject in supine lying, lift the leg few (up to 10) inches while keeping leg straight hold for } 10 \text { seconds and rest for } \\
10 \text { seconds, } 3 \text { sets of } 10 \text { repetitions thrice a week for } 2 \text { weeks [10] }\end{array}$} \\
\hline Abductor rise & \multicolumn{2}{|r|}{$\begin{array}{l}\text { Lie on side, propped on one elbow. The leg on the floor bent, the other straight. Slowly lift the top leg, hold for } \\
\text { 5-10 seconds, then lower. Do } 3 \text { sets with } 10 \text { repetitions each for } 2 \text { weeks }\end{array}$} \\
\hline Adductor rise & \multicolumn{2}{|r|}{$\begin{array}{l}\text { Lie on side, propped on one elbow. The leg on the floor straight, the other leg abducted and supported by examiner } \\
\text { slowly lift the affected leg } 6-8^{\prime \prime} \text {, hold for } 5-10 \text { seconds, then lower. Do } 3 \text { sets with } 10 \text { repetitions each for } 2 \text { weeks }\end{array}$} \\
\hline Hamstring curl & \multicolumn{2}{|r|}{$\begin{array}{l}\text { Subject in prone position with a resistance band tied around ankle. Slowly bend knee tightening the back of } \\
\text { thigh (hamstrings). Perform } 3 \text { sets of } 10 \text { repetitions provided the exercise is pain free }\end{array}$} \\
\hline Quadriceps curl & \multicolumn{2}{|r|}{$\begin{array}{l}\text { Begin this exercise in sitting with your knee bent and a resistance band tied around ankle. Keeping your back straight, } \\
\text { slowly straighten your knee tightening the front of thigh (quadriceps). Perform } 3 \text { sets of } 10 \text { repetitions provided it is } \\
\text { pain free for } 2 \text { weeks }\end{array}$} \\
\hline Wall squats & \multicolumn{2}{|r|}{$\begin{array}{l}\text { Lean your back and buttocks against a wall, with your legs shoulder-width apart. Your feet should be between } 6-14^{\prime \prime} \\
\text { away from the wall. Slowly slide down the wall by bending your knees until they are at about a } 45^{\circ} \text { angle (bend less if } \\
\text { you experience pain). Pause, then slowly slide back up to your starting position. Perform three sets of } 10-15 \text { repetitions } \\
\text { for } 2 \text { weeks }\end{array}$} \\
\hline One leg balance & \multicolumn{2}{|r|}{$\begin{array}{l}\text { Stand on with one leg with relaxed and upright posture, other leg is flexed the knee so that it is off the ground. Weight } \\
\text { bearing leg should be slightly flexed at knee, hip and ankle, hold this position for } 1 \text { minute rest for } 20 \text { seconds. } 2 \text { sets of } 5 \\
\text { repetitions thrice a week for } 2 \text { weeks [1] }\end{array}$} \\
\hline Toe walking & \multicolumn{2}{|r|}{$\begin{array}{l}\text { Subject was made to walk for } 20 \mathrm{~m} \text { distance up on the toes pointing straight ahead, then walk with toes pointing out rest } \\
\text { for } 20 \text { seconds } 2 \text { sets of } 5 \text { repetitions thrice a week for } 2 \text { weeks [1] }\end{array}$} \\
\hline Heel walking & \multicolumn{2}{|c|}{$\begin{array}{l}\text { Walking for } 20 \mathrm{~m} \text { on heel with toes pointing straight ahead, toes pointing out and toes pointing in and rest for } \\
20 \text { seconds } 2 \text { sets of } 5 \text { repetitions thrice a week for } 2 \text { weeks [1] }\end{array}$} \\
\hline Cross body leg swings & \multicolumn{2}{|r|}{$\begin{array}{l}\text { leaning slightly forward with hands on a wall for support and weight on affected leg, other leg was swing in front of the } \\
\text { body, this was repeated for } 10 \text { times and brief rest. } 2 \text { sets of } 5 \text { repetitions thrice a week for } 2 \text { weeks [1] }\end{array}$} \\
\hline Wobble board & \multicolumn{2}{|r|}{$\begin{array}{l}\text { Stand on the balance board and try to keep it level. Weight shifting side to side, diagonally, Return the board to a level } \\
\text { position in between taps, When you can do this exercise with good control, try it on one leg, or with eyes closed } 2 \text { sets of } \\
5 \text { repetitions thrice a week for } 2 \text { weeks [14] } \\
\text { Level } 1 \quad \text { A. Pelvic-lift with flexed knees and short lever arm, putting load on both legs }\end{array}$} \\
\hline \multirow[t]{3}{*}{$\begin{array}{l}\text { Core stability/postural } \\
\text { function }\end{array}$} & Level 1 & $\begin{array}{l}\text { A. Pelvic-lift with flexed knees and short lever arm, putting load on both legs } \\
\text { B. Sit-ups with flexed knees, both legs on ball, arms along the sides (short lever) }\end{array}$ \\
\hline & Level 2 & $\begin{array}{l}\text { A. Pelvic-lift with semi-flexed knees and long lever arm, putting load on both legs } \\
\text { B. Sit-ups with flexed knees, both legs on ball, arms crossed over chest (medium lever }\end{array}$ \\
\hline & Level 3 & $\begin{array}{l}\text { A. Pelvic-lift as above, alternately putting load on the affected and non-affected legs } \\
\text { B. Sit-ups with flexed knees, both legs on ball, hands behind neck (long lever arm) }\end{array}$ \\
\hline \multirow[t]{3}{*}{ Postural orientation } & Level 1 & $\begin{array}{l}\text { A. Slide-exercise forward-backward: Standing, weight-bearing on one leg, other leg on sliding surface. Slide } \\
\text { backward - forward with "sliding leg," while flexing - extending the knee of the weight-bearing leg and } \\
\text { keeping an appropriate position of the joints in relation to each other } \\
\text { B. Slide-exercise sideways: Standing, weight-bearing on one leg, other leg on sliding surface. Slide } \\
\text { sideways with "sliding leg," while flexing - extending the knee of the weight-bearing leg and keeping an } \\
\text { appropriate position of the joints in relation to each other }\end{array}$ \\
\hline & Level 2 & $\begin{array}{l}\text { A. Slide-exercise forward - backward: As above, standing on uneven surface (e.g., foam pillow or thick } \\
\text { mattress) } \\
\text { B. Slide-exercise sideways: As above, standing on uneven surface }\end{array}$ \\
\hline & Level 3 & $\begin{array}{l}\text { A. Forward lunge: Standing position, take a large step forward and then return. Hand support for balance if } \\
\text { needed } \\
\text { B. Sideway lunge: Standing position, take a large step sideways and then return. Hand support for balance if } \\
\text { needed. } 2 \text { sets of } 3 \text { repetitions thrice a week for } 2 \text { weeks [15] }\end{array}$ \\
\hline Step up and step down & $\begin{array}{l}\text { Subject } \\
\text { up onto } \\
\text { repetitic }\end{array}$ & $\begin{array}{l}\text { e to stand in front of a step, like a sturdy bench or stairs, about two feet high (or less if necessary). Step } \\
\text { support, straighten subject knees fully (without locking them) and step down for } 2 \text { minutes } 2 \text { sets of } 3 \\
\text { hrice a week for } 2 \text { weeks [15] }\end{array}$ \\
\hline
\end{tabular}

physiotherapists who have hitherto concentrated almost exclusively on quadriceps strengthening in $\mathrm{OA}$ patients to include hamstrings, adductors, and abductors strengthening in their management protocol (Table 2).

In this study, we found that there were significance differences between pre- and post-intervention measures in VAS, ROM, muscle strength and functional outcome of the knee joint (Figs. 1-5).
The stabilization protocol applied by us lasted for 8 weeks, in thrice a week session. There is a clinical and statistical difference between pre- and post-intervention values of pain, muscle strength and knee ROM, and there is no statistical significance in the values of serum COMP values.

The primary concern of this study is the small number of subjects and the lack of control group. This limits the possibilities of interpreting the results and controlling for possible confounders. 
Table 3: Results

\begin{tabular}{|c|c|c|c|c|c|}
\hline \multicolumn{6}{|l|}{ Paired sample statistics } \\
\hline Components & Mean & $\mathbf{N}$ & $\begin{array}{l}\text { Standard } \\
\text { deviation }\end{array}$ & $\begin{array}{l}\text { Standard } \\
\text { error mean }\end{array}$ & \\
\hline Pre VAS & 6.30 & 20 & 1.160 & 0.367 & \multirow[t]{2}{*}{0.000} \\
\hline Post VAS & 3.30 & 20 & 0.675 & 0.213 & \\
\hline Pre knee ROM flex & 93.50 & 20 & 13.134 & 4.153 & \multirow[t]{2}{*}{0.002} \\
\hline Post knee ROM flex & 107.00 & 20 & 8.233 & 2.603 & \\
\hline Pre knee flexors strength & 11.80 & 20 & 5.903 & 1.867 & \multirow[t]{2}{*}{0.009} \\
\hline Post knee flexors strength & 13.50 & 20 & 6.346 & 2.007 & \\
\hline Pre knee extensors strength & 11.00 & 20 & 5.907 & 1.868 & \multirow{2}{*}{0.00} \\
\hline Post knee extensors strength & 15.40 & 20 & 6.467 & 2.045 & \\
\hline Pre COMP value & 509.00 & 20 & 34.785 & 11.000 & \multirow[t]{2}{*}{0.678} \\
\hline Post COMP value & 510.00 & 20 & 31.972 & 10.111 & \\
\hline
\end{tabular}

VAS: Visual analog scale, ROM: Range of motion, COMP: Cartilage oligomeric matrix protein

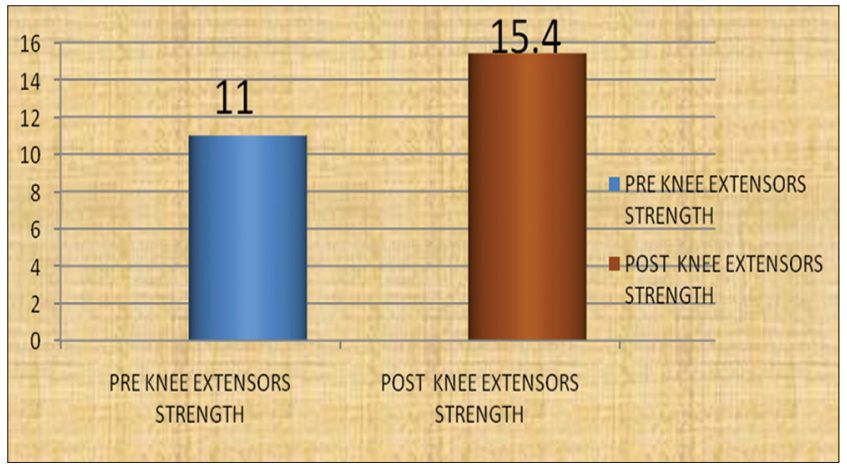

Fig. 4: Knee extensors strength

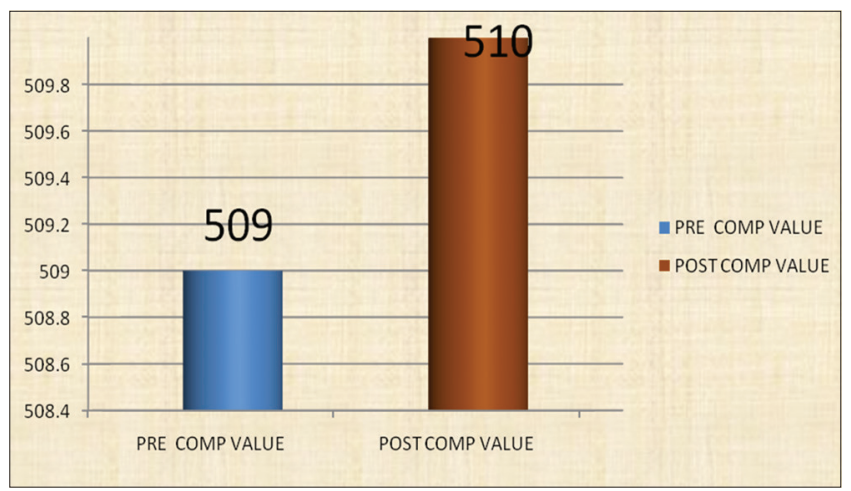

Fig. 5: Cartilage oligomeric matrix protein value

\section{CONCLUSION}

Stabilization exercises of knee joint were shown to be beneficial for decreasing pain, improving ROM and muscle strength, and there was no effect on articular cartilage changes in degenerative tibiofemoral joint disease.

\section{ACKNOWLEDGMENT}

I take this opportunity to express my profound gratitude and deep regards to Dr. Ganni Bhaskara Rao, Chairman, GSL Educational Institutions for his cordial support and guidance. I am grateful to the Ethical Committee headed by Dr. Antony Leo for giving clearance for my thesis. I take this pleasant and unique opportunity to express my deep sense of gratitude and offer my most sincere and humble thanks to my research guide Dr. Sudhakar, who helped me to shape my Thesis well right from the beginning. I would like to thank Dr. S. G. Sudhan for his encouragement and guidance. We acknowledge the great help received from the scholars/publishers of all those articles cited and included in the references of this manuscript. We are also grateful to the editors/publishers of all those articles, journals and books from where the literature for this article has been reviewed and discussed. The authors are grateful to AJPCR editorial board members and AJPCR team of reviewers who have helped to bring quality to this manuscript. I thank almighty, my parents, my Brother and Friends for their constant encouragement without which this assignment is not possible.

\section{REFERENCES}

1. Mondam S, Babu S. A Comparative study of proprioceptive exercises versus conventional training program on osteoarthritis of knee. Res $\mathrm{J}$ Recent Sci 2012;1(12):31-5.

2. Power JD, Badley EM, French MR, Wall AJ, Hawker GA. Fatigue in osteoarthritis: A qualitative study. BMC Musculoskelet Disord 2008;9:63.

3. Tanna S. Osteoarthritis: Oppurtunities to Address Pharmaceutical Gaps. October; 2004

4. Symmons D, Mathers C. Global burden of osteoarthritis. Global Burden of Disease; Geneva: World Health Organization; 2000.

5. Mahajan A, Verma S, Tandon V. Osteoarthritis. J Assoc Physicians India 2005;53:634-41.

6. Awadallah A, Sabry GH. Serum level of cartilage oligomeric matrix protein as a screening modality for osteoarthritis among knee joint pain patients. J Am Sci 2010;6(12):1059-1066.

7. Wislowska M, Jablonska B. Serum cartilage oligomeric matrix protein (COMP) in rheumatoid arthritis and knee osteoarthritis. Clin Rheumatol 2005;24(3):278-84.

8. Odunaiya NA. The effects of static stretch duration on the flexibility of hamstring muscles. Afr J Biomed Res 2005;8:79-82.

9. Johanson MA, Cuda BJ, Koontz JE, Stell JC, Abelew TA. Effect of stretching on ankle and knee angles and gastrocnemius activity during the stance phase of gait. J Sport Rehabil 2009;18(4):521-34.

10. Anwer S, Alghadir A. Effect of isometric quadriceps exercise on muscle strength, pain, and function in patients with knee osteoarthritis: A randomized controlled study. J Phys Ther Sci 2014;26(5):745-8.

11. Magdy I, Naggar E. Functional performance in patients with knee osteoarthritis after isometric versus isotonic training. Bull Fac Pharm Cairo Univ 2006;11: 163-175.

12. Gryzlo SM, Patek RM, Pink M, Perry J. Electromyographic analysis of knee rehabilitation exercises. J Orthop Sports Phys Ther 1994;20(1):36-43.

13. Andersen LL, Magnusson SP, Nielsen M, Haleem J, Poulsen K, Aagaard P. Neuromuscular activation in conventional therapeutic exercises and heavy resistance exercises: Implications for rehabilitation. Phys Ther 2006;86(5):683-97.

14. Reinold MM, Wilk KE, Macrina LC, Dugas JR, Cain EL. Current concepts in the rehabilitation following articular cartilage repair procedures in the knee. J Orthop Sports Phys Ther 2006;36(10):774-94.

15. Ageberg E, Link A, Roos EM. Feasibility of neuromuscular training in patients with severe hip or knee OA: The individualized goalbased NEMEX-TJR training program. BMC Musculoskelet Disord 2010;11:126.

16. Knoop J, van der Leeden M, Roorda LD, Thorstensson CA, van der Esch M, Peter WF, et al. Knee joint stabilization therapy in patients with osteoarthritis of the knee and knee instability: Subgroup analyses in a randomized, controlled trial. J Rehabil Med 2014;46(7):703-7. 